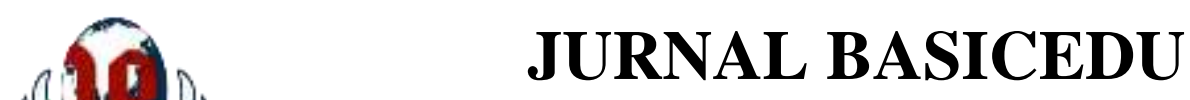

Volume 5 Nomor 6 Tahun 2021 Halaman 6025 - 6033

Research \& Learning in Elementary Education

https://jbasic.org/index.php/basicedu

PAHLAMAN

\title{
Pengaruh Penggunaan Model Pembelajaran Kooperatif Tipe Think Pair Share terhadap Motivasi dan Hasil Belajar Belajar Siswa Kelas VI
}

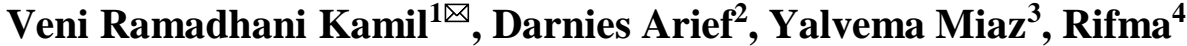 \\ Universitas Negeri Padang, Indonesia ${ }^{1,2,3,4}$ \\ E-mail: veniramadhanikamil@gmail.com ${ }^{1}$, nis.darnis@gmail.com² ${ }^{2}$, yalmiaz@gmail.com³ \\ rifmar34@gmail.com ${ }^{4}$
}

\begin{abstract}
Abstrak
Masih banyak siswa kelas VI SDN 05 Pasar Tiku yang belum mencapai KKM sehingga ini menjadi alasan untuk melakukan penelitian ini. Salah satu upaya yang dapat dilakukan untuk meningkatka hasil belajar adalah dengan menerapkan Model Pembelajaran Kooperatif tipe Think Pair Share (TPS). Jenis penelitian ini adalah penelitian eksperimen dengan design penelitian pretest-posttest control group design. Populasi penelitian yaitu seluruh siswa kelas VI SDN 05 Pasar Tiku. Data yang diambil dalam penelitian ini adalah skor angket motivasi belajar dan hasil tes yang didapat melalui pretest dan posttest, angket dalam bentuk pernyataan dan soal dalam bentuk objektif. Hasil penelitian menunjukkan bahwa adanya perbedaan antara kelas eksperimen yang diajarkan dengan menggunakan model pembelajaran TPS dibandingkan dengan kelas kontrol yang hanya menggunakan metode konvensional. Hal ini dapat dibuktikan dari nilai rata-rata nilai pretest hasil belajar kelas ekperimen lebih tinggi dari pada kelas kontrol Begitu juga dengan nilai rata-rata posttest hasil belajar kelas ekperimen lebih tinggi dari pada kelas control. Dari hasil uji hipotesis pretest dengan menggunakan uji-t diperoleh bahwa $\mathrm{t}_{\text {hitung }}>\mathrm{t}_{\text {tabel }}=8,9341>1,7056$. Begitupun dengan hasil hasil uji hipotesis postest dengan menggunakan uji- $\mathrm{t}$ diperoleh bahwa $t_{\text {hitung }}>t_{\text {tabel }}=9,92684>1,7056$. Dapat disimpulkan bahwa model pembelajaran TPS berpengaruh terhadap motivasi dan hasil belajar siswa kelas VI SDN 05 Pasar Tiku.
\end{abstract}

Kata Kunci: Motivasi, Hasil Belajar, Model Pembelajaran Think Pair Share

\begin{abstract}
There are still many sixth-grade students at SDN 05 Pasar Tiku who have not yet reached the KKM, so this is the reason for conducting this research. One of the efforts that can be done to improve learning outcomes is to apply the Think Pair Share (TPS) Cooperative Learning Model. This type of research is an experimental study with a pretest-posttest control group design. The research population is all students of class VI SDN 05 Pasar Tiku. The data taken in this study were the score of the learning motivation questionnaire and the test results obtained through the pretest and posttest, questionnaires in the form of statements, and questions in objective form. The results showed that there was a difference between the experimental class which was taught using the TPS learning model compared to the control class which only used conventional methods. This can be proven from the average value of the pretest value of the experimental class learning outcomes which is higher than the control class. Likewise, the posttest average value of the experimental class learning outcomes is higher than the control class. From the results of the pretest hypothesis test using the $t$-test, it was found that tcount $>$ t table $=8.9341>1.7056$. Likewise, with the results of the posttest hypothesis test using the $t$-test, it was found that tcount $>t$ table $=9.92684>1.7056$. It can be concluded that the TPS learning model affects the motivation and learning outcomes of class VI SDN 05 Pasar Tiku students.
\end{abstract}

Keywords: Motivation, Learning Outcomes, Think Pair Share Learning Model

Copyright (c) 2021 Veni Ramadhani Kamil, Darnies Arief, Yalvema Miaz, Rifma

Corresponding author :

Email : veniramadhanikamil@gmail.com

DOI : https://doi.org/10.31004/basicedu.v5i6.1744

ISSN 2580-3735 (Media Cetak)

ISSN 2580-1147 (Media Online)

Jurnal Basicedu Vol 5 No 6 Tahun 2021

p-ISSN 2580-3735 e-ISSN 2580-1147 
6026 Pengaruh Penggunaan Model Pembelajaran Kooperatif Tipe Think Pair Share terhadap Motivasi dan Hasil Belajar Belajar Siswa Kelas VI - Veni Ramadhani Kamil, Darnies Arief, Yalvema Miaz, Rifma DOI: https://doi.org/10.31004/basicedu.v5i6.1744

\section{PENDAHULUAN}

Hasil belajar dapat dikatakan berhasil jika terjadi perubahan pada diri peserta didik. Hasil belajar merupakan tolak ukur yang dapat digunakan untuk menentukan tingkat keberhasilan siswa dalam memahami konsep belajar, apabila telah terjadi perubahan tingkah laku pada seseorang, maka seseorang dapat dikatakan telah berhasil dalam belajar (Miaz, 2012)). Interaksi antara guru dan siswa akan efektif jika berlangsung dua arah. Guru diharapkan menciptakan proses pembelajaran yang dapat memunculkan respons siswa. Respons siswa dapat dilihat dari partisipasi siswa selama proses pembelajaran (Kunci, 2014)).

(Yousif et al., 2018)) menyatakan bahwa dalam belajar sangat diperlukan motivasi belajar, hasil belajar akan menjadi optimal jika ada motivasi. Semakin tepat motivasi yang diberikan, akan semakin berhasil juga pelajaran itu. Menurut (Zain \& Ahmad, 2021)) Jika tidak ada motivasi dari siswa untuk belajar, maka selamanya siswa tidak akan tertarik dengan pelajaran dan tidak memperoleh kepuasan dari belajar dan belajar menjadi tidak bermakna.Hal tersebut sejalan dengan penelitian yang dilakukan oleh (Lusidawaty et al., 2020)) untuk belajar sangat diperlukan adanya motivasi, adanya motivasi yang tinggi dalam belajar akan manunjukkan hasil yang baik. Motivasi berpengaruh dalam meningkatkan hasil belajar siswa.

Guru sebagai sumber belajar, penentu metode dan model pembelajaran, dan juga penilai kemajuan belajar siswa untuk menjadikan pembelajaran lebih efektif dan efisien untuk mencapai tujuan pembelajaran itu sendiri ((Husada et al., 2020)). Salah satu upaya yang dapat dilakukan oleh guru untuk meningkatkan motivasi belajar siswa yaitu dengan pemilihan model pembelajaran yang tepat. Pemilihan model pembelajaran harus disesuaikan dengan materi yang akan disampaikan, jika model yang diterapkan tidak sesuai dengan tingkat kesukaran materi ajar maka akan menimbulkan ketidak singkronan dalam proses pembelajaran. Pembelajaran yang menarik dapat menumbuhkan motivasi belajar siswa, sehingga hasil belajar siswa akan meningkat. Model pembelajaran adalah suatu perencanaan atau pola yang dapat kita gunakan untuk mendesain pola-pola mengajar secara tatap muka di dalam kelas, untuk menentukan material atau perangkat pembelajaran termasuk di dalamnya bukubuku, media pembelajaran dan kurikulum (Fitria, 2018)).

Dalam dunia pendidikan khususnya di Indonesia sedang dikembangkan sebuah model pembelajaran dengan pendekatan kontekstual, di mana salah satu cirinya adalah kooperatif atau disebut juga strategi belajar kelompok atau kerja sama (Supomo, 2018)Adanya suatu pembelajaran yang lebih tepat dan menarik perlu dilaksanakan, dimana siswa dapat belajar secara kooperatif, dapat bertanya meskipun tidak pada guru secara langsung, mengemukakan pendapat dan interaksi siswa lebih meningkat (Abdi \& Hasanuddin, 2018)). Sejalan dengan pendapat ((Irianto, 2016)) yang menyatakan think pair share sebagai salah satu tipe dalam pembelajaran kooperatif, memberi kesempatan pada siswa untuk berpikir, berpasangan atau bekerja dengan partner, berbagi, dan saling membantu satu sama lain, sehingga mampu menambah variasi model pembelajaran yang lebih menarik, menyenangkan, meningkatkan aktivitas, serta kerja sama siswa.

Sedangkan ((Usma, 2015)) the think-pair-share strategy is a strategy designed to provide students to think a given topic by enabling them to formulate individual ideas and share these ideas with another student. This strategy is a learning strategy developed by Lyman to encourage student classroom participation The thinkpair-share strategy is a cooperative discussion strategy to help students work in group. ((Riva Prathiwi et al., 2014) menggunakan model pembelajaran kooperatif tipe Think Pair Share Siswa dapat membangun interaksi dan proses sosial yang baik dalam proses belajar mengajar dan meningkatkan motivasi siswa untuk belajar secara berdiskusi dikelas. (Anita Lie, 2010) juga menyatakan model pembelajaran TPS merupakan model pembelajaran yang dapat membantu memberikan motivasi kepada siswa di dalam proses pembelajaran. Model pembelajaran ini bertujuan untuk mempermudah pengelolaan informasi, komunikasi, dan mengembangkan cara berpikir siswa dalam mengikuti pembelajaran,

((Fitriani \& Wuryandari, 2019)) menyatakan bahwa kerjasama setiap siswa dalam mengikuti pembelajaran adalah salah satu faktor penentu keberhasilan belajar siswa itu sendiri. Dalam kurikulum 2013 
6027 Pengaruh Penggunaan Model Pembelajaran Kooperatif Tipe Think Pair Share terhadap Motivasi dan Hasil Belajar Belajar Siswa Kelas VI - Veni Ramadhani Kamil, Darnies Arief, Yalvema Miaz, Rifma DOI: https://doi.org/10.31004/basicedu.v5i6.1744

kemampuan kerjasama sangat diperlukan karena dalam pembelajaran tematik integratif pada menganut pendekatan scientific yang mana siswa diminta untuk berkelompok dalam menyelesaikan permasalahan bersama. Bekerja sama berarti mampu menyelesaikan suatu hal dengan orang lain untuk mencapai tujuan bersama. Kerja sama sangat penting untuk dimiliki oleh setiap siswa, melalui kerja sama mereka dapat mengembangkan kemampuan komunikasi, menghargai perbedaan, kepedulian, dan pencapaian tujuan kelompok.

Berdasarkan observasi lapangan dan wawancara peneliti pada 10 dan 11 Februari 2021 dan 20 Juli 2021 dengan guru kelas VI SDN 05 Pasar Tiku, Peneliti menemukan beberapa permasalahan diantaranya; Pembelajaran yang dilaksanakan guru kurang dapat menarik perhatian dan motivasi siswa dalam belajar. Pembelajaran yang dilaksanakan guru yaitu berupa pembelajaran satu arah yang mengakibatkan siswa bosan dan konsep dari materi pembelajaran hanya sedikit yang tertinggal dipikiran siswa. Guru terlihat kurang bersemangat untuk memotivasi siswa belajar dan berpikir kritis. Hal ini ditandai dengan guru menyampaikan materi pelajaran yang hanya memberikan penjelasan dengan menggunakan metode ceramah. Guru juga tidak terlihat menggunakan media apapun dalam penyampaian materi pembelajaran. Guru jarang menggunakan model pembelajaran berkelompok, kalaupun itu pernah dilakukan guru, namun guru tidak memperhatikan aspek-aspek model pembelajaran berkelompok yang seharusnya. Misalnya, waktu ketika melaksanakan model pembelajaran berkelompok, guru tidak membagi siswa secara heterogen serta guru tidak membimbing siswa bagaimana sikap yang baik disaat diskusi kelompok.

Permasalah tersebut berdampak terhadap hasil belajar siswa kelas VI pada nilai ulangan harian semester ganjil tahun pelajaran 2021/2022 diperoleh data sebagian besar siswa belum mencapai Kriteria Ketuntasan Minimun (KKM) yang ditetapkan yaitu 75. Terlihat pada data ketuntasan hasil belajar kelas VI pada ulangan harian semester 1 tahun pelajaran 2021/2022.

Penerapan model pembelajaran kooperatif tipe TPS membantu siswa untuk membiasakan bertanya kepada guru, keberanian mengemukakan pendapat, dan dapat bekerja sama dengan baik (Darlin, 2015).Dengan cara menggunakan model pembelajaran yang inovatif siswa akan lebih fokus dan asik untuk belajar. Di sini peneliti mengguakan model Think Pair Share (TPS). Model Think Pair Share merupakan salah satu tipe pembelajaran kooperatif yang dapat menciptakan pembelajaran yang efektif dan menyenangkan, mengurangi tingkat kejenuhan, mampu memberikan motivasi, dan dapat meningkatkan hasil belajar. Model pembelajaran TPS ini bertujuan untuk mempermudah dalam pengelolaan informasi, komunikasi, dan mengembangkan cara berpikir siswa dalam mengikuti pembelajaran.

Berdasarkan penelitian yang dilakukan (L et al., 2017) dengan menggunakan model koperatif Tipe TPS diperoleh hasil penelitian yaitu adanya peningkatan hasil belajar IPS dari 76,75\% ke 89,67\% (sangat baik). Sedangkan (Puspitasari et al., 2016)tentang peningkatan motivasi dan hasil belajar IPS melalui model TPS di sekolah dasar diperoleh hasil penelitian yaitu (1) terdapat peningkatan motivasi belajar melalui TPS dengan skor rata-rata siklus I ke siklus II sebesar 18\%. (2) terdapat peningkatan hasil belajar melalui TPS dengan skor rata-rata siklus I ke siklus II sebesar 14\%. Berdasarkan pendapat di atas dapat disimpulkan bahwa model TPS cocok digunakan untuk meningkatkan motivasi dan hasil belajar siswa.

\section{METODE}

Penelitian yang di adakan ini adalah termasuk sebuah penelitian ekperimen (ekperimen research). Eksperimen dapat di artikan sebagai proses penelitian yang digunakan untuk mencari pengaruh dari suatu perlakuan terhadap yang lain dalam kondisi yang telah terkendali. Ekrperimen dalam penelitian ini yaitu eksperimen tipe pretest-posttest control group design. Dalam melakukan penelitian ekperimen dibutuhkan dua kelas, peneliti mengambil dua kelas pada Kelas VI yang akan djadikan sebagai kelas ekperimen dan kelas kelas kontrol. Penelitian ini menggunakan model Think Pair Share yang bertujuan untuk mengetahui hasil belajar siswa apakah meningkat dari sebelumnya yang hanya menggunakan metode ceramah saja. 
6028 Pengaruh Penggunaan Model Pembelajaran Kooperatif Tipe Think Pair Share terhadap Motivasi dan Hasil Belajar Belajar Siswa Kelas VI - Veni Ramadhani Kamil, Darnies Arief, Yalvema Miaz, Rifma DOI: https://doi.org/10.31004/basicedu.v5i6.1744

Dengan dua kelas yang di ambil, yakni ada kelas ekperimen dan kelas kontrol, kelompok eksperimen adalah kelompok kelas yang diberikan perlakuan metode baru yakni pembelajaran dengan menggunakan model Think Pair Share (TPS) dan kelas kontrol adalah kelompok kelas yang diajarakan secara biasa tanpa melibatkan model pembelajaran apapun. Populasi penelitian ini adalah seluruh siswa kelas VI SDN 05 Pasar Tiku yang terdaftar pada semester I tahun ajaran 2021/2022. Pengambilan sampel secara Sampling Purposive. Dalam pelaksanaan penelitian, untuk memperoleh data maka dilakukan langkah-langkah sebagai berikut: memberikan angket motivasi dan kerjasama siswa pada kelas eksperimen dan kelas kontrol. Memberikan tes pada kelas eksperimen dan kelas kontrol setelah diberikan perlakuan. Teknik yang digunakan dalam penganalisisan data penelitian sebagai berikut: analisis butir angket motivasi dan kerjasama siswa, analisis data hasil belajar siswa, uji normalitas, homogenitas, dan uji hipotesis. (Sudjana, 2016)

\section{HASIL DAN PEMBAHASAN}

\section{Uji Normalitas}

Uji normalitas nilai tes kemampuan pemecahan masalah dan komunikasi matematis siswa kelas eksperimen dan kelas kontrol dilakukan dengan menggunakan uji Lilliefors pada taraf signifikan a $=0,05$. Hasilnya dapat dillihat pada tabel dibawah ini.

PRETEST

Tabel 1

Uji Normalitas Pretest Hasil Belajar

\begin{tabular}{ccccccc}
\hline No & Kelompok & $\mathrm{N}$ & $\mathrm{A}$ & $\mathrm{L}_{0}$ & $\mathrm{~L}_{\mathrm{t}}$ & Keterangan \\
\hline 1 & Eksperimen & 14 & 0,05 & $-0,00934$ & 0,227 & Normal \\
2 & Kontrol & 14 & 0,05 & 0,00643 & 0,227 & Normal \\
\hline
\end{tabular}

Berdasarkan tabel diatas dapat dilihat bahwa kedua kelas tersebut berdistribusi normal

Tabel 2

Uji Normalitas Pretest Hasil Motivasi Belajar Tinggi

\begin{tabular}{ccccccc}
\hline No & Kelompok & $\mathrm{N}$ & $\mathrm{A}$ & $\mathrm{L}_{0}$ & $\mathrm{~L}_{\mathrm{t}}$ & Keterangan \\
\hline 1 & Eksperimen & 7 & 0,05 & 0,28866 & 0,300 & Normal \\
2 & Kontrol & 7 & 0,05 & 0,27736 & 0,300 & Normal \\
\hline
\end{tabular}

Berdasarkan tabel diatas dapat dilihat bahwa kedua kelas tersebut berdistribusi normal

Tabel 3

Uji Normalitas Pretest Hasil Motivasi Belajar Rendah

\begin{tabular}{ccccccc}
\hline No & Kelompok & N & A & L $_{0}$ & $\mathrm{~L}_{t}$ & Keterangan \\
\hline 1 & Eksperimen & 7 & 0,05 & 0,2974 & 0,300 & Normal \\
2 & Kontrol & 7 & 0,05 & 0,2971 & 0,300 & Normal \\
\hline
\end{tabular}

Berdasarkan tabel diatas dapat dilihat bahwa bahwa kedua kelas tersebut berdistribusi normal POSTTEST

Tabel 4

Uji Normalitas Posttest Hasil Belajar

\begin{tabular}{ccccccc}
\hline No & Kelompok & $\mathrm{N}$ & $\mathrm{A}$ & $\mathrm{L}_{0}$ & $\mathrm{~L}_{\mathrm{t}}$ & Keterangan \\
\hline 1 & Eksperimen & 14 & 0,05 & 0,1338 & 0,227 & Normal \\
2 & Kontrol & 14 & 0,05 & 0,1237 & 0,227 & Normal \\
\hline
\end{tabular}

Berdasarkan tabel diatas dapat dilihat bahwa kedua kelas tersebut berdistribusi normal 
6029 Pengaruh Penggunaan Model Pembelajaran Kooperatif Tipe Think Pair Share terhadap Motivasi dan Hasil Belajar Belajar Siswa Kelas VI - Veni Ramadhani Kamil, Darnies Arief, Yalvema Miaz, Rifma DOI: https://doi.org/10.31004/basicedu.v5i6.1744

Uji Normalitas Posttest Hasil Motivasi Belajar Tinggi

\begin{tabular}{ccccccc}
\hline No & Kelompok & $\mathrm{N}$ & $\mathrm{A}$ & $\mathrm{L} 0$ & $\mathrm{Lt}$ & Keterangan \\
\hline 1 & Eksperimen & 7 & 0,05 & 0,2974 & 0,300 & Normal \\
2 & Kontrol & 7 & 0,05 & 0,2825 & 0,300 & Normal \\
\hline
\end{tabular}

Berdasarkan tabel diatas dapat dilihat bahwa kedua kelas tersebut berdistribusi normal

Tabel 6

Uji Normalitas Posttest Hasil Motivasi Belajar Rendah

\begin{tabular}{ccccccc}
\hline No & Kelompok & N & A & L0 & Lt & Keterangan \\
\hline 1 & Eksperimen & 7 & 0,05 & 0,2825 & 0,300 & Normal \\
2 & Kontrol & 7 & 0,05 & 0,2971 & 0,300 & Normal \\
\hline
\end{tabular}

Berdasarkan tabel diatas dapat dilihat bahwa kedua kelas tersebut berdistribusi normal

\section{Uji Homogenitas}

Uji homogenitas dilakukan bertujuan untuk mengetahui apakah data berasal dari kedua kelas tersebut homogen atau tidak, maka dilakukan melalui uji F.

\section{PRETEST}

Tabel 7

Uji Homogenitas Pretest Hasil Belajar

\begin{tabular}{ccccc}
\hline Kelompok & $\mathrm{A}$ & $\mathrm{F}_{\text {hitung }}$ & $\mathrm{F}_{\text {tabel }}$ & Kesimpulan \\
\hline $\begin{array}{c}\text { Eksperimen } \\
\text { Kontrol }\end{array}$ & 0,05 & 1,3660 & 2,5769 & Homogen \\
\hline
\end{tabular}

Dari tabel diatas terlihat bahwa Fhitung $<$ Ftabel, 1,3660<2,5769 kedua kelas tersebut memiliki varians yang homogen.

Tabel 8

Uji Homogenitas Pretest Hasil Motivasi Belajar Tinggi

\begin{tabular}{ccccc}
\hline Kelompok & $\mathrm{A}$ & $\mathrm{F}_{\text {hitung }}$ & $\mathrm{F}_{\text {tabel }}$ & Kesimpulan \\
\hline $\begin{array}{c}\text { Eksperimen } \\
\text { Kontrol }\end{array}$ & 0,05 & 1,5483 & 4,2838 & Homogen \\
\hline
\end{tabular}

Dari tabel diatas terlihat bahwa Fhitung $<$ Ftabel, 1,5483<4,2838, kedua kelas tersebut memiliki varians yang homogen.

Tabel 9

Uji Homogenitas Pretest Hasil Motivasi Belajar Rendah

\begin{tabular}{ccccc}
\hline Kelompok & $\mathrm{A}$ & $\mathrm{F}_{\text {hitung }}$ & $\mathrm{F}_{\text {tabel }}$ & Kesimpulan \\
\hline $\begin{array}{c}\text { Eksperimen } \\
\text { Kontrol }\end{array}$ & 0,05 & 1,4354 & 4,2838 & Homogen \\
\hline
\end{tabular}

Dari tabel diatas terlihat bahwa Fhitung $<$ Ftabel, 1,4354<4,2838, kedua kelas tersebut memiliki varians yang homogen.

POSTTEST

Tabel 10

Uji Homogenitas Posttest Hasil Belajar

\begin{tabular}{ccccc}
\hline Kelompok & $\mathrm{A}$ & $\mathrm{F}_{\text {hitung }}$ & $\mathrm{F}_{\text {tabel }}$ & Kesimpulan \\
\hline $\begin{array}{c}\text { Eksperimen } \\
\text { Kontrol }\end{array}$ & 0,05 & 0,7822 & 2,5769 & Homogen \\
\hline
\end{tabular}

Dari tabel diatas terlihat bahwa Fhitung $<$ Ftabel, 0,7822<2,5769, kedua kelas tersebut memiliki varians yang homogen.

Tabel 11

Uji Homogenitas Posttest Hasil Motivasi Belajar Tinggi 
6030 Pengaruh Penggunaan Model Pembelajaran Kooperatif Tipe Think Pair Share terhadap Motivasi dan Hasil Belajar Belajar Siswa Kelas VI - Veni Ramadhani Kamil, Darnies Arief, Yalvema Miaz, Rifma DOI: https://doi.org/10.31004/basicedu.v5i6.1744

\begin{tabular}{ccccc}
\hline Kelompok & $\mathrm{A}$ & $\mathrm{F}_{\text {hitung }}$ & $\mathrm{F}_{\text {tabel }}$ & Kesimpulan \\
\hline $\begin{array}{c}\text { Eksperimen } \\
\text { Kontrol }\end{array}$ & 0,05 & 1,9777 & 4,2838 & Homogen \\
\hline
\end{tabular}

Dari tabel diatas terlihat bahwa Fhitung $<$ Ftabel, 1,9777<4,2838, kedua kelas tersebut memiliki varians yang homogen.

Tabel 12

Uji Homogenitas Posttest Hasil Motivasi Belajar Rendah

\begin{tabular}{ccccc}
\hline Kelompok & $\mathrm{A}$ & $\mathrm{F}_{\text {hitung }}$ & $\mathrm{F}_{\text {tabel }}$ & Kesimpulan \\
\hline $\begin{array}{c}\text { Eksperimen } \\
\text { Kontrol }\end{array}$ & 0,05 & 0,7258 & 4,2838 & Homogen \\
\hline
\end{tabular}

Dari tabel diatas terlihat bahwa Fhitung $<$ Ftabel, 0,7258<4,2838, kedua kelas tersebut memiliki varians yang homogen.

\section{Uji Hipotesis}

Uji hipotesis dengan menggunakan:

Jika Thitung> Ttabel maka H0 ditolak dan $\mathrm{H} 1$ diterima

Jika Thitung $<$ Ttabel maka H0 diterima dan $\mathrm{H} 1$ ditolak

PRETEST

Tabel 13

Uji Hipotesis Pretest Hasil Belajar

\begin{tabular}{cccc}
\hline Kelas & $\mathrm{t}_{\text {hitung }}$ & $\mathrm{t}_{\text {tabel }}$ & Kesimpulan \\
\hline $\begin{array}{c}\text { Eksperimen } \\
\text { Kontrol }\end{array}$ & 8,9341615 & 1,70562 & $\mathrm{t}_{\text {hitung }}>\mathrm{t}_{\text {tabel }}$ \\
\hline
\end{tabular}

Dapat disimpulkan bahwa $\mathrm{H} 1$ diterima dan $\mathrm{H} 0$ ditolak

Tabel 14

Uji Hipotesis Pretest Hasil Motivasi Belajar Tinggi

\begin{tabular}{cccc}
\hline Kelas & $\mathrm{t}_{\text {hitung }}$ & $\mathrm{t}_{\text {tabel }}$ & Kesimpulan \\
\hline $\begin{array}{c}\text { Eksperimen } \\
\text { Kontrol }\end{array}$ & 5,1449 & 1,78229 & $\mathrm{t}_{\text {hitung }}>\mathrm{t}_{\text {tabel }}$ \\
\hline
\end{tabular}

Dapat disimpulkan bahwa $\mathrm{H} 1$ diterima dan $\mathrm{H} 0$ ditolak

Tabel 15

Uji Hipotesis Pretest Hasil Motivasi Belajar Rendah

\begin{tabular}{cccc}
\hline Kelas & $\mathrm{t}_{\text {hitung }}$ & $\mathrm{t}_{\text {tabel }}$ & Kesimpulan \\
\hline $\begin{array}{c}\text { Eksperimen } \\
\text { Kontrol }\end{array}$ & 5,7735 & 1,78229 & $\mathrm{t}_{\text {hitung }}>\mathrm{t}_{\text {tabel }}$ \\
\hline
\end{tabular}

Dapat disimpulkan bahwa $\mathrm{H} 1$ diterima dan $\mathrm{H} 0$ ditolak

POSTTEST

Tabel 16

Uji Hipotesis Posttest Hasil Belajar

\begin{tabular}{cccc}
\hline Kelas & $\mathrm{t}_{\text {hitung }}$ & $\mathrm{t}_{\text {tabel }}$ & Kesimpulan \\
\hline $\begin{array}{c}\text { Eksperimen } \\
\text { Kontrol }\end{array}$ & 9,926846 & 1,70562 & $\mathrm{t}_{\text {hitung }}>\mathrm{t}_{\text {tabel }}$ \\
\hline
\end{tabular}

Dapat disimpulkan bahwa $\mathrm{H} 1$ diterima dan $\mathrm{H} 0$ ditolak 

Hasil Belajar Belajar Siswa Kelas VI - Veni Ramadhani Kamil, Darnies Arief, Yalvema Miaz, Rifma DOI: https://doi.org/10.31004/basicedu.v5i6.1744

Tabel 17

Uji Hipotesis Posttest Hasil Motivasi Belajar Tinggi

\begin{tabular}{cccc}
\hline Kelas & $\mathrm{t}_{\text {hitung }}$ & $\mathrm{t}_{\text {tabel }}$ & Kesimpulan \\
\hline $\begin{array}{c}\text { Eksperimen } \\
\text { Kontrol }\end{array}$ & 15,37708 & 1,78229 & $\mathrm{t}_{\text {hitung }}>\mathrm{t}_{\text {tabel }}$ \\
\hline
\end{tabular}

Dapat disimpulkan bahwa H1 diterima dan H0 ditolak

Tabel 18

Uji Hipotesis Posttest Hasil Motivasi Belajar Rendah

\begin{tabular}{cccc}
\hline Kelas & $\mathrm{t}_{\text {hitung }}$ & $\mathrm{t}_{\text {tabel }}$ & Kesimpulan \\
\hline $\begin{array}{c}\text { Eksperimen } \\
\text { Kontrol }\end{array}$ & 7,236272 & 1,78229 & $\mathrm{t}_{\text {hitung }}>\mathrm{t}_{\text {tabel }}$ \\
& & & \\
\hline
\end{tabular}

Dapat disimpulkan bahwa $\mathrm{H} 1$ diterima dan $\mathrm{H} 0$ ditolak

TPS merupakan suatu model pembelajaran yang disusun untuk memecahkan masalah, model TPS merupakan gabungan strategi individual dan kelompok dengan memberikan permasalahan nyata kepada siswa dan melatih siswa mengkomunikasikan ide matematisnya dengan membuat gambar, simbol dan penjelasan dalam bentuk tulisan dengan bahasa sendiri untuk menyelesaikan masalahnya. Siswa memecahkan masalah secara individual kemudian siswa mengkomunikasikannya di dalam kelompok untuk didiskusikan dan saling dibahas, dimana semua anggota kelompok bertanggung jawab atas keseluruhan jawaban sebagai tanggung jawab bersama dan mempersentasikannya di depan kelas. Sehingga siswa dapat terlatih dalam kemampuan komunikasi matematisnya (Fitri et al., 2020)

Penelitian yang dilakukan (Santra et al., 2018)) membuktikan bahwa kegiatan pembelajaran dengan menerapkan model think pair share berbantuan power point mampu meningkatkan kemampuan pemecahan masalah, keaktifan, antusias, dan kemampuan berbicara siswa. Sehingga berpengaruh terhadap tingkap pemahaman siswa dan hasil belajar IPA siswa.

Pada penelitian ini di dapat bahwa motivasi belajar siswa meningkat dilihat dari analisis data pretest ratarata motivasi belajar kelas eksperimen yaitu 71,42 lebih baik dari kelas kontrol 68,21 dan jumlah nilai kelas eksperimen (1000) lebih tinggi dari pada kelas kontrol (955). Setelah diterapkannya model pembelajaran Think Pair Share (TPS) nilai siswa kelas eksperimen semakin baik berdasarkan posttest motivasi belajar jumlah skor kelas eksperimen (1125) lebih tinggi dari pada kelas kontrol (1030).

Begiru juga pada analisis data pretest rata-rata hasil belajar pada kelas eksperimen yaitu 72,85 lebih baik dari pada kelas kontrol 69,64 dan jumlah nilai kelas eksperimen (1020) lebih tinggi dari pada kelas kontrol (975). Setelah diterapkannya model pembelajaran Think Pair Share (TPS) nilai siswa kelas eksperimen semakin baik berdasarkan posttest hasil belajar jumlah skor kelas eksperimen (1200) lebih tinggi dari pada kelas kontrol (1150). Membuktikan bahwa kegiatan pembelajaran dengan menerapkan model think pair share dapat meningkatkan motivasi dan hasil belajar siswa.

\section{KESIMPULAN}

Penelitian ini merupakan penelitian yang membandingkan penggunaan model Think Pair Share (TPS) dan pendekatan konvensional. Penelitian ini bertujuan untuk melihat pengaruh penggunaan model think pair share dan kerjasama terhadap hasil belajar dan motivasi belajar siswa kelas VI. Berdasarkan analisis data yang telah dikemukakan, maka dapat disimpulkan bahwa 1) Rata-rata hasil yang dilihat dari pretest dan posttest kelas eksperimen lebih tinggi dari kelas kontrol. Adanya perbedaan antara hasil belajar kelas eksperimen dan kelas kontrol, hal ini berarti bahwa adanya pengaruh model pembelajaran Think Pair Share (TPS) dan Kerjasama terhadap hasil belajar dan motivasi belajar kelas VI di SDN 05 Pasar Tiku. 2) Siswa yang memiliki motivasi belajar tinggi yang mengikuti pembelajaran dengan menggunakan model TPS lebih tinggi dibandingkan siswa yang belajar dengan pendekatann konvensional 3) Siswa yang memiliki motivasi belajar rendah yang mengikuti 
6032 Pengaruh Penggunaan Model Pembelajaran Kooperatif Tipe Think Pair Share terhadap Motivasi dan Hasil Belajar Belajar Siswa Kelas VI - Veni Ramadhani Kamil, Darnies Arief, Yalvema Miaz, Rifma DOI: https://doi.org/10.31004/basicedu.v5i6.1744

pembelajaran dengan menggunakan model TPS lebih tinggi dibandingkan siswa yang belajar dengan pendekatann konvensional 4) Siswa yang memiliki kerjasama tinggi yang mengikuti pembelajaran dengan menggunakan model TPS lebih tinggi dibandingkan siswa yang belajar dengan pendekatann konvensional 5) Siswa yang memiliki kerjasama rendah yang mengikuti pembelajaran dengan menggunakan model TPS lebih tinggi dibandingkan siswa yang belajar dengan pendekatann konvensional

\section{DAFTAR PUSTAKA}

Abdi, M., \& Hasanuddin, H. (2018). Pengaruh Model Pembelajaran Think Pair Share dan Motivasi Belajar terhadap Kemampuan Komunikasi Matematis Siswa Sekolah Menengah Pertama. JURING (Journal for Research in Mathematics Learning), 1(2), 99. https://doi.org/10.24014/juring.v1i2.4778

Anita Lie. (2010). Cooperative Learning. Gramedia Widiasarana Indonesia.

Darlin. (2015). Penggunaan Model Cooperative Learning Tipe Think Pairs Hare Untuk Meningkatkan Hasil Belajar PKN pada Siswa Kelas V SD Inpres Duyu. Jurnal Kreatif Tadulako Online, 4(7), 257.

Fitri, R., Neviyarni, N., \& Zikri, A. (2020). Pembelajaran PKn dengan Model Cooperative Learning Tipe Talking Stick di Sekolah Dasar. Jurnal Basicedu, 4(1), 183-193.

https://doi.org/10.31004/basicedu.v4i1.322

Fitria, Y. (2018). Perubahan Belajar Sains Siswa Sekolah Dasar Pada Pembelajaran Terintegrasi (Terpadu) Melalui Model Discovery Learning. Jurnal Inovasi Pendidikan Dan Pembelajaran Sekolah Dasar, 2(2), 52. https://doi.org/10.24036/jippsd.v2i2.102705

Fitriani, K., \& Wuryandari, W. (2019). Jurnal Civics: Media Kajian Kewarganegaraan Pengaruh model kooperatif tipe Think Pair Share terhadap kerja sama siswa. 16(1), 80-88.

Husada, S. P., Taufina, T., \& Zikri, A. (2020). Pengembangan Bahan Ajar Pembelajaran Tematik dengan Menggunakan Metode Visual Storytelling di Sekolah Dasar. Jurnal Basicedu, 4(2), 419-425. https://doi.org/10.31004/basicedu.v4i2.373

Irianto, P. O. (2016). Pengaruh Model Pembelajaran Kooperatif Tipe Think Pair Share Terhadap Keterampilan Menulis Teks Deskripsi Siswa Kelas Vii Smp Negeri 1 Padang. 2(November).

Kunci, K. (2014). Memperkokoh Pendidikan Karakter Melalui Mediasi Aktivitas Jasmani Berbasis Nilai. Jurnal Pendidikan Karakter, 2, 121576. https://doi.org/10.21831/jpk.v0i2.2180

L, J., U, K., \& S, R. (2017). Hasil Belajar Dan Pembelajaran Kooperatif Tipe Tps. Jurnal Pendidikan Indonesia, 6(1), 96-105.

Lusidawaty, V., Fitria, Y., Miaz, Y., \& Zikri, A. (2020). Pembelajaran Ipa Dengan Strategi Pembelajaran Inkuiri Untuk Meningkatkan Keterampilan Proses Sains Dan Motivasi Belajar Siswa Di Sekolah Dasar. Jurnal Basicedu, 4(1), 168-174. https://doi.org/10.31004/basicedu.v4i1.333

Miaz, Y. (2012). Penggunaan Pendekatan Sains Teknologi Masyarakat Untuk Meningkatkan Hasil Belajar Siswa Dalam Pembelajaran IPS Kelas IV SDN 01 Baringin Anam Baso Kabupaten Agam. Universitas Negeri Padang, 350, 1-53.

https://www.academia.edu/39366716/Konsep_Pendekatan_Dalam_Pembelajaran_Pendekatan_Kontekst ual_Konstruktivisme_Deduktif_Induktif_Dan_Konsep_

Puspitasari, E., Setyosari, P., \& Amirudin, A. (2016). Peningkatan Motivasi Dan Hasil Belajar Melalui Think Pair Share (Tps) Di Sekolah Dasar. Jurnal Pendidikan - Teori, Penelitian, Dan Pengembangan, 1(7), 1432-1436. https://doi.org/10.17977/jp.v1i7.6589

Riva Prathiwi, J., Dantes, N., \& Natajaya, N. (2014). Pengaruh Implementasi Model Pembelajaran Kooperatif Tipe Think Pair Share (TPS) Terhadap Motivasi Belajar dan Prestasi Belajar Dalam Pembelajaran IPS Pada Siswa Kelas V Sekolah Dasar Gugus VIII Kecamatan Buleleng. E-Journal Program Pascasarjana Universitas Pendidikan Ganesha, 4, 4. 
6033 Pengaruh Penggunaan Model Pembelajaran Kooperatif Tipe Think Pair Share terhadap Motivasi dan Hasil Belajar Belajar Siswa Kelas VI - Veni Ramadhani Kamil, Darnies Arief, Yalvema Miaz, Rifma DOI: https://doi.org/10.31004/basicedu.v5i6.1744

Santra, P., Wibawa, I. M. C., \& Rati, N. W. (2018). Pengaruh Model Pembelajaran Think Pair Share Berbantuan Power Point Terhadap Hasil Belajar Ipa. International Journal of Elementary Education, 1(4), 307. https://doi.org/10.23887/ijee.v1i4.12962

Sudjana. (2016). Metode Statistika. Transito.

Supomo, W. E. (2018). Pengaruh Model Think-Pair-Share (Tps) Untuk Meningkatkan Motivasi Belajar Siswa Dalam Pembelajaran Pendidikan Kewarganegaraan Di Kelas Vii Smp Kartika Iv 8 Malang Tahun Pelajaran 2017/2018. Jurnal Ilmiah Fakultas Keguruan Dan Ilmu Pendidikan, 19(1), 89-99.

Usma, A. H. (2015). Using the think-pair-share strategy to improve students speaking ability at stain ternate. Journal of Education and Practice, 6(10), 37-46.

Yousif, N., Cole, J., Rothwell, J. C., Diedrichsen, J., Zelik, K. E., Winstein, C. J., Kay, D. B., Wijesinghe, R., Protti, D. A., Camp, A. J., Quinlan, E., Jacobs, J. V, Henry, S. M., Horak, F. B., Jacobs, J. V, Fraser, L. E., Mansfield, A., Harris, L. R., Merino, D. M., ... Dublin, C. (2018). No 主観的健康感を中心とした 在宅高齢者における 健康関連指標に関する共分散構造分析Title. Journal of Physical Therapy Science, 9(1), 1-11.

http://dx.doi.org/10.1016/j.neuropsychologia.2015.07.010http://dx.doi.org/10.1016/j.visres.2014.07.001 https://doi.org/10.1016/j.humov.2018.08.006http://www.ncbi.nlm.nih.gov/pubmed/24582474https://doi. org/10.1016/j.gaitpost.2018.12.007https://doi.org/

Zain, B. P., \& Ahmad, R. (2021). Pengaruh Model Kooperatif Tipe Think Pair Share terhadap Motivasi dan Kemampuan Komunikasi Matematis Siswa Sekolah Dasar. Jurnal Basicedu, 5(5), 4120-4126. http://www.jbasic.org/index.php/basicedu/article/view/1347 